\title{
Effect of sprouted papaya seed meal on physiological conditions, intestinal bacterial populations and meat quality of broilers
}

\author{
S. Sugiharto*, W. Winarti, E. Widiastuti, T. Yudiarti, \\ T. A. Sartono, H. I. Wahyuni and A. R. Pratama \\ Department of Animal Science, Faculty of Animal and Agricultural Sciences, \\ Universtas Diponegoro, Tembalang Campus, Semarang 50275 - Indonesia \\ *CorrespondingE-mail: sgh_undip@yahoo.co.id \\ Received August 17, 2021; Accepted November 20, 2021
}

\begin{abstract}
The study investigated the effect of sprouted papaya seed meal (SPSM) on physiological conditions, intestinal bacteria and meat quality of broilers. A 390 broiler chicks were distributed to T0 (control feed), T1 (feed with 2.5\% papaya seed meal [PSM]), T2 (1\% SPSM), T3 (2.5\% SPSM), and T4 (5\% SPSM). Blood, intestinal digesta and meat were obtained at day 36. Feeding 2.5\% PSM lowered $(\mathrm{P}<0.05)$, but SPSM up to $5 \%$ had no effect on daily gain. PSM reduced $(\mathrm{p}<0.05)$ feed intake, but not SPSM. Feed efficiency was lower $(\mathrm{P}<0.05)$ in T4. Feeding 5\% SPSM increased $(\mathrm{P}=0.06)$ bursa of fabricius. T1, T3 and T4 had lower $(\mathrm{P}=0.09)$ heterophils. Mean corpuscular haemoglobin and mean corpuscular haemoglobin concentration were lower $(\mathrm{P}<0.05)$ in T4. Cholesterol to high-density lipoprotein (HDL) ratio of PSM and SPSM was lower $(\mathrm{P}<0.05)$ than control. SPSM at $2.5 \%$ increased $(\mathrm{P}<0.05)$ serum HDL. $\mathrm{PSM}-\mathrm{fed}$ birds had lower cholesterol $(\mathrm{P}=0.07)$, triglyceride $(\mathrm{P}=0.09)$ and lowdensity lipoprotein $(\mathrm{P}=0.09)$. PSM or SPSM decreased $(\mathrm{P}<0.05)$ serum total protein, albumin and globulin. PSM and SPSM reduced $(\mathrm{P}<0.05)$ creatinine. Alanine aminotransferase was reduced $(\mathrm{P}<0.05)$ with SPSM at 1 and 2.5\%. Ileal lactic acid bacteria to coliform ratio in PSM and SPSM was greater $(\mathrm{P}<0.05)$ than in control. Ileal coliform was lower $(\mathrm{P}=0.08)$ in PSM and SPSM. PSM reduced $(\mathrm{P}=0.08)$ saturated fatty acids, while 1 and $2.5 \%$ SPSM increased $(\mathrm{P}=0.09)$ unsaturated fatty acids contents of meats. In conclusion, SPSM improved immune competence, blood lipid profile and gut bacterial population of broilers.
\end{abstract}

Keywords: antioxidant, broiler, germination, seed, stress

\section{INTRODUCTION}

Modern broiler strains have generally been attributed to fast growth rates, efficient feed utilization, and a short production time. Apart from its superiority, broiler chickens are very vulnerable to stress induced by intensive rearing management. Indeed, stress are associated with retarded growth rate, disrupted physiological conditions, imbalanced intestinal microbiology, as well as impaired meat quality (Sugiharto et al., 2017). Subtherapeutic antibiotics and synthetic antioxidants have been employed in broiler production to counteract the negative effects of stress. Yet, the long-term use of subtherapeutic antibiotics and/or synthetic antioxidants may leave residues on meats that are hazardous to consumers' health. This might lead to the use of subtherapeutic antibiotics being prohibited and synthetic antioxidants being restricted in broiler 
farming. Following the removal and restriction respectively of antibiotics and synthetic antioxidants from broiler diets, functional feeds have recently received a lot of interest as feed ingredients. Sugiharto et al. (2018) suggested that functional feed may serve compounds that promote broiler health and growth.

Papaya (Carica papaya L.) seed has been incorporated in broiler diet either as a feed ingredient to reduce the proportion of soybean meal (Bolu et al., 2009) or as functional feed ingredient to exert health improvement in broilers (Adegbeye et al., 2020). Papaya seed contains $30.1 \%$ crude protein (Bolu et al., 2009), and also several bioactive compounds including alkaloid, tannin, phenol, saponin, and flavonoid, which can serve as antimicrobial, immune modulator, and antioxidants (Sugiharto, 2020a). Aside from its useful properties, the use of papaya seed in broiler diet has been limited by its high fibre (24.3\%; Azevedo and Campagnol, 2014) and anti-nutritional components (Sugiharto, 2020a), which thereby impairs the digestibility of chicks. Germination or sprouting is one of the simple methods to increase protein and amino acids, reduce crude fibre, improve fibre fraction as well as reduce anti-nutritional components of seeds (Hooda and Jood, 2003; Nkhata et al., 2018). Sprouting has also been reported to improve the functional properties of seeds. In this regards, sprouting has been documented to enhance the antioxidant and antimicrobial activities of seeds (Sehrawat et al., 2020).

Several sprouted seeds have been included in broiler diets, for instances mung bean, red sorghum, barley, pearl millet, buckwheat, soybean, etc. (Sugiharto, 2021). Yet, the use of sprouted papaya seed in broiler feed has never been reported so far. Therefore, the present study aimed to investigate the effect of sprouted papaya seed meal (SPSM) on physiological conditions, intestinal bacterial populations and meat quality of broiler chickens.

\section{MATERIALS AND METHODS}

\section{Production of SPSM}

The ripe papaya seed was collected from street vendors around the university. The seed was washed with running water and then spread on tray at room temperature for about 24 hours. The papaya seeds were soaked for 24 hours, and subsequently put in perforated bucket. The seed was allowed to germinate for two weeks. Each day, the seed in bucket was sprinkled with water to maintain the seed wet during the sprouting process. After this period, the sprouted seed was collected, sun-dried, and finely ground. To produce papaya seed meal (PSM), the ripe papaya seed was directly sun-dried after being washed using running water. The seed was then finely ground and placed in room temperature until use for in vivo experiment. For proximate analysis, about $100 \mathrm{~g}$ sample of PSM and SPSM was obtained. Data on proximate composition of PSM and SPSM are presented in Table 1.

\section{In vivo experiment}

Three hundred and ninety day-old Lohmann broiler chicks were fed with commercial starter diet having $23.0 \%$ crude protein, $5.0 \%$ crude fibre, $5.0 \%$ crude fat, and $7.0 \%$ ash (based on feed label) from day 0 to 14 . Starting from days 14 , the birds were randomly distributed to T0 (chicks received basal feed), T1 (feed with 2.5\% PSM), T2 (feed with 1\% SPSM), T3 (feed with $2.5 \%$ SPSM), and T4 (feed with 5\% SPSM). The study was conducted based on a completely randomized design (CRD), with five groups and six replicates. Each replicate contained 13 birds, and thus each dietary group had 78 birds. An opensided chicken house was used to raise the birds during the experiment, with rice husk was used as bedding material. Throughout the rearing period, a constant lighting schedule was implemented. The feeds were prepared in mash form to be isocaloric and isonitrogenous (Table 2). The Indonesian National Standard for broiler finisher feed was used as a reference during feed formulation. The chicks were vaccinated with Newcastle disease vaccine on days 4 and 18, and Gumboro vaccine on day 12. Daily weight gain (DWG) was determined as = (final body weight - initial weight)/days of treatment. Daily feed intake (DFI) was defined as = (feed offered leftover feed)/days of feeding, while feed efficiency was estimated by dividing the body weight gain by the feed intake during treatment, and then multiplying the result by $100 \%$.

At the end of experiment (day 36), two male broilers from each replicate/pen were taken and sample of blood was collected from their wing vein using disposable $3 \mathrm{~mL}$ syringe. The blood was put in ethylenediaminetetraacetic acid (EDTA) containing vacutainer for the determination of complete blood counts, and the remaining blood was placed in vacutainer-free anticoagulant for the production of serum. The Prima Ful- 
Table 1. Proximate Compositions of Papaya Seed and Sprouted Papaya Seed Meals

\begin{tabular}{lll}
\hline \multicolumn{1}{c}{ Compositions (\% DM) } & PSM & SPSM \\
\hline Moisture & 7.19 & 10.3 \\
Crude protein & 21.7 & 24.7 \\
Crude fat & 22.9 & 21.2 \\
Crude fibre & 38.7 & 36.9 \\
Ash & 10.8 & 6.67 \\
\hline DM: dry matter, PSM: papaya seed meal, SPSM: sprouted papaya seed meal
\end{tabular}

Table 2. Ingredients and Chemical Compositions of Feeds (Days 14-36)

\begin{tabular}{|c|c|c|c|c|c|}
\hline $\begin{array}{l}\text { Variables } \\
(\%, \text { unless otherwise noted })\end{array}$ & T0 & $\mathrm{T} 1$ & $\mathrm{~T} 2$ & $\mathrm{~T} 3$ & $\mathrm{~T} 4$ \\
\hline Yellow maize & 58.5 & 57.0 & 58.1 & 57.3 & 56.1 \\
\hline Palm oil & 3.00 & 3.00 & 2.90 & 2.90 & 2.80 \\
\hline SBM & 34.7 & 33.7 & 34.2 & 33.5 & 32.3 \\
\hline PSM & - & 2.50 & - & - & - \\
\hline SPSM & - & - & 1.00 & 2.50 & 5.00 \\
\hline DL-methionine & 0.19 & 0.19 & 0.19 & 0.19 & 0.19 \\
\hline Bentonite & 0.75 & 0.75 & 0.75 & 0.75 & 0.75 \\
\hline Limestone & 0.75 & 0.75 & 0.75 & 0.75 & 0.75 \\
\hline MCP & 1.30 & 1.30 & 1.30 & 1.30 & 1.30 \\
\hline Premix & 0.34 & 0.34 & 0.34 & 0.34 & 0.34 \\
\hline Chlorine chloride & 0.07 & 0.07 & 0.07 & 0.07 & 0.07 \\
\hline Salt & 0.40 & 0.40 & 0.40 & 0.40 & 0.40 \\
\hline \multicolumn{6}{|c|}{ Calculated chemical compositions: } \\
\hline $\mathrm{ME},(\mathrm{kcal} / \mathrm{kg})^{1}$ & 3,000 & 3,000 & 3,000 & 3,000 & 3,000 \\
\hline Crude protein & 20.0 & 20.0 & 20.0 & 20.0 & 20.0 \\
\hline Crude fibre & 5.51 & 6.33 & 5.83 & 6.30 & 7.08 \\
\hline \multicolumn{6}{|l|}{$\begin{array}{l}\text { Analyzed chemical composition } \\
\text { (on dry basis): }\end{array}$} \\
\hline Moisture & 12.7 & 14.3 & 13.2 & 13.2 & 11.9 \\
\hline Crude protein & 22.9 & 25.1 & 22.1 & 23.9 & 24.9 \\
\hline Crude fat & 4.55 & 5.18 & 4.89 & 4.72 & 5.16 \\
\hline Crude fibre & 8.18 & 8.82 & 9.37 & 9.92 & 9.96 \\
\hline Ash & 6.85 & 6.32 & 5.79 & 5.90 & 9.38 \\
\hline \multicolumn{6}{|c|}{$\begin{array}{l}{ }^{1} \text { ME (metabolizable energy) was estimated based on formula (Bolton, 1967): } 40.81\{0.87 \text { [crude protein }+ \\
2.25 \text { crude fat }+ \text { nitrogen-free extract] }+2.5\} \\
\text { T0: chicks received basal feed, T1: feed with } 2.5 \% \text { PSM, T2: feed with } 1 \% \text { SPSM, T3: feed with } 2.5 \% \\
\text { SPSM, T4: feed with } 5 \% \text { SPSM, PSM: papaya seed meal, SPSM: sprouted papaya seed meal, SBM: soybean } \\
\text { meal, MCP: monocalcium phosphate }\end{array}$} \\
\hline
\end{tabular}

ly-Auto Hematology Analyzer (PT. Prima Alkesindo Nusantara, Jakarta, Indonesia) was employed to measure the complete blood counts based on the manufacturer's description. For the production of serum, the collected blood was let at room temperature for about 2 hours. To separate the serum and blood clot, the blood was centrifuged for 10 minutes at 5,000 rpm. The serum was then kept in the freezer $\left(\right.$ at $\left.-10^{\circ} \mathrm{C}\right)$ until analysis. After the blood was taken, one of the two birds was slaughtered. The internal organs were obtained and weighed (in empty condition). For the enumeration of selected bacterial population, the digesta was collected from ileum and caecum of broilers immediately after slaughter. The sample of breast meat was also collected from broiler, and kept frozen $\left(\right.$ at $-10^{\circ} \mathrm{C}$ ) until the analysis of fatty acid profile and meat colour.

The serum lipid, uric acid, and creatinine levels were measured using enzyme-based colorimetric techniques. Spectrophotometric/ photometric assays were used to assess total se- 
rum protein, albumin, glucose, alanine aminotransferase (ALT), and aspartate aminotransferase (AST). To calculate the globulin concentration, total protein in serum was deducted from albumin in serum. The serum biochemistry tests were carried out according to the manufacturer's guidance (DiaSys Diagnostic System GmbH, Holzheim, Germany). Coliform and lactosenegative Enterobacteriaceae were enumerated as red and colourless colonies on MacConkey agar (Merck KGaA, Darmstadt, Germany) after 24 hours of aerobic incubation at $38^{\circ} \mathrm{C}$. The sum of coliform and lactose-negative Enterobacteriaceae was regarded as Enterobacteriaceae. Following anaerobic incubation at $38^{\circ} \mathrm{C}$ for 48 hours on MRS agar (Merck KGaA), the numbers of lactic acid bacteria (LAB) were counted.

A digital colour meter running on Mac OS $\mathrm{X}$ was used to verify the colour of the meat (set to CIE Lab). L* (lightness), a* (redness), and b* (yellowness) values were used to indicate the colour. A traditional gas chromatography method was used to evaluate the fatty acid content of breast meats. The presence of fatty acids was evaluated by comparing the retention periods of each sample to the standard retention times. The area percentage was normalized and adjusted to $\mathrm{g}$ per $100 \mathrm{~g}$ of edible part for fatty acid measurement using a lipid conversion factor. To determine total saturated fatty acids (SFA) and unsaturated fatty acids (UFA), each component of SFA and UFA was added individually.

\section{Statistical analysis}

The data were statistically treated according to CRD using analysis of variance (ANOVA, SPSS 16.0 version). The Duncan multi-range test was employed when dietary treatments showed a significant effect $(\mathrm{P}<0.05)$. The $0.05 \leq \mathrm{P}<0.10$ was regarded as a trend.

\section{RESULTS AND DISCUSSION}

The incorporation of $2.5 \%$ PSM in feed resulted in lower $(\mathrm{P}<0.05)$ daily weight gain of broilers in the current investigation (Table 3). Different from PSM, the inclusion of SPSM up to $5 \%$ in diets had no meaningful effect $(\mathrm{P}>0.05)$ on the daily gain of broilers. This seemed to be accounted to the improved nutrient quality of SPSM due to germination, with regards particularly to its increased protein and decreased fibre contents (Table 1). Likewise, the reduced content of anti-nutritional components in SPSM with sprouting process may increase feed digestibility and thereby nutrient availability for growth (Sugiharto, 2020a). There was an absence effect $(\mathrm{P}>0.05)$ of feeding SPSM up to $5 \%$ on daily feed intake of broiler, when compared with the birds fed on control diet (Table 3). Conversely, feeding PSM reduced $(\mathrm{P}<0.05)$ daily feed intake of broilers. This may be attributed to the presences of anti-nutritional factors (Sugiharto, 2020a) and low-digested fibre (lignin, cellulose and hemicellulose; Adesuyi and Ipinmoroti, 2011) in PSM that can impair feed digestibility and intake. In this study, feed efficiency was lower $(\mathrm{P}<0.05)$ in broiler fed 5\% SPSM, as compared to other birds. It was most likely that the higher fibre content of the respective feed (Table 2) may compromise feed digestibility and thus weight gain of broilers.

When comparing broilers fed a diet containing 5\% SPSM to those fed a control diet, there was an apparent trend $(\mathrm{P}=0.06)$ for the relative weight of bursa of fabricius to be greater (Table 4). Numerous variables influence the development of the bursa of fabricius, one of which is stress. In the study of Tarek et al. (2013), the decrease in bursa of fabricius weight has been attributed to stressful environment leading to oxidative stress. In our case, the increased antioxidative compounds in sprouting seeds (Sehrawat et al., 2020) appeared to offset the detrimental effect of stress on bursa of fabricius development. Overall, it was therefore worth noting that antioxidant compounds found in SPSM are critical for reducing the detrimental effects of stress on broiler's immune competences (Sugiharto, 2020a).

Table 5 shows complete blood counts of broiler chickens at day 36. In this study, it was discovered that giving $2.5 \%$ PSM or SPSM at levels of $2.5 \%$ and $5 \%$ of feeds resulted in a decrease $(\mathrm{P}=0.09)$ in heterophils values. Modern broiler strains have typically been raised in a stressful environment with restricted access to natural behaviour, inadequate cleanliness, high stocking density, and a high ambient temperature. In poultry, the rise in heterophils levels is usually attributed to the stressful environment (Maxwell and Robertson, 1998; Kontecka et al., 1999) as well as inflammation owing to pathogenic bacterial invasion (Harmon, 1998). Given these circumstances, it was possible that feeding PSM or SPSM might help to relieve the stressful condition, therefore avoiding the excessive increase in heterophils production. As compared to those in other birds, $\mathrm{MCH}$ and $\mathrm{MCHC}$ levels in broilers given SPSM were lower $(\mathrm{P}<0.05)$ especially when administered at $5 \%$ in feed. The $\mathrm{MCH}$ and MCHC levels were often greater in chickens exposed to stressful conditions (Kontecka et al., 1999; Aengwanich, 2007). This might be a stressrelated physiological reaction, in which birds increase their oxygen-carrying capacity to assist their energyproducing metabolism. It should be noted that stressed birds require more energy than non-stressed birds. Overall, because of the increased concentration of antioxidative compounds in SPSM ingested, it was possible that broilers given a diet containing 5\% 
SPSM experienced less oxidative stress.

The cholesterol to HDL ratio in the serum of broilers fed PSM or SPSM was lower $(\mathrm{P}<0.05)$ in the current research than in the serum of those fed a control diet (Table 6). The impaired immune competences of broilers is often associated with a greater cholesterol to HDL ratio (dyslipidemia) (Sugiharto, 2020b). In this case, giving PSM or SPSM to broiler chickens therefore appeared to be advantageous to their health and well-being. In this study, feeding SPSM at a rate of $2.5 \%$ resulted in a higher $(\mathrm{P}<0.05)$ serum HDL level than either the control or PSM diet. It was most likely that the flavonoids content in SPSM was responsible for the increased HDL-cholesterol level of broilers as reported by Ouyang et al. (2016). In this study, the birds fed on PSM tended to have lower total cholesterol $(\mathrm{P}=0.07)$, triglyceride $(\mathrm{P}=0.09)$ and LDL-cholesterol $(\mathrm{P}=0.09)$ when compared with control birds. In a prior study, Sarikhan et al. (2009) found that consuming insoluble fibre in the diet reduced cholesterol, triglyceride, and LDL-cholesterol levels in broiler blood. Insoluble fibre may enhance cholesterol and bile acid excretion in the faeces, ac- cording to the researchers. It was shown in this study that the reduction in serum total cholesterol, triglyceride, and LDL-cholesterol levels seemed to be more pronounced in PSM fed than SPSM fed broilers. As suggested previously that germination may improve the fibre fractions (i.e., increase soluble fibre content) of seeds (Hooda and Jood, 2003; Nkhata et al., 2018). In the earlier study, Razdan et al. (1997) compared between chitosan (considered as insoluble fibre) and pectin (soluble fibre) with regard to their capacity in lowering total plasma cholesterol of broilers. They noticed that chitosan was more effective in reducing plasma cholesterol concentration than that of pectin. One possible reason for these differences is that birds on the pectin diet had greater bile acid resorption than those on the chitosan diet, which is likely because pectin may only bind superficially to bile acids, but chitosan may sequester bile acids more firmly. On this background, it could be understood that PSM was more prominent than SPSM in lowering cholesterol, triglycerides, and LDL.

It was reported in the current study that dietary inclusion of PSM or SPSM decreased $(\mathrm{P}<0.05)$ serum

Table 3. Growth Performance of Broilers (Days 14-36)

\begin{tabular}{|c|c|c|c|c|c|c|c|}
\hline Variables & T0 & $\mathrm{T} 1$ & $\mathrm{~T} 2$ & $\mathrm{~T} 3$ & $\mathrm{~T} 4$ & SEM & $P$ value \\
\hline DWG, g/d & $61.4^{\mathrm{a}}$ & $54.3^{b}$ & $60.9^{\mathrm{a}}$ & $57.9^{\mathrm{ab}}$ & $58.1^{\mathrm{ab}}$ & 0.78 & 0.02 \\
\hline DFI, g/d & $102^{\mathrm{a}}$ & $94.4^{\mathrm{b}}$ & $105^{\mathrm{a}}$ & $102^{\mathrm{a}}$ & $109^{\mathrm{a}}$ & 1.36 & $<0.01$ \\
\hline FE, \% & $60.0^{\mathrm{a}}$ & $57.7^{\mathrm{a}}$ & $57.9^{\mathrm{a}}$ & $56.8^{\mathrm{ab}}$ & $53.3^{\mathrm{b}}$ & 0.66 & 0.02 \\
\hline \multicolumn{8}{|c|}{$\begin{array}{l}{ }^{a, b} \text { Within the same row, the means with different superscript characters varied substantially } \\
(\mathrm{P}<0.05)\end{array}$} \\
\hline
\end{tabular}

Table 4. Relative Internal Organ Weight of Broilers at Day 36

\begin{tabular}{lccccccc}
\hline Variables (\% live BW) & Variables & T0 & T1 & T2 & T3 & SEM & P value \\
\hline Heart & 0.48 & 0.52 & 0.47 & 0.55 & 0.54 & 0.01 & 0.35 \\
Liver & 2.42 & 2.25 & 2.15 & 2.04 & 2.22 & 0.07 & 0.62 \\
Proventriculus & 0.51 & 0.54 & 0.56 & 0.53 & 0.57 & 0.01 & 0.37 \\
Gizzard & 1.57 & 1.74 & 1.70 & 1.63 & 1.88 & 0.04 & 0.21 \\
Pancreas & 0.25 & 0.26 & 0.28 & 0.26 & 0.26 & 0.01 & 0.88 \\
Duodenum & 0.57 & 0.60 & 0.61 & 0.47 & 0.60 & 0.02 & 0.23 \\
Jejunum & 1.38 & 1.22 & 1.29 & 1.16 & 1.12 & 0.06 & 0.66 \\
Ileum & 0.74 & 0.76 & 0.79 & 0.85 & 0.81 & 0.03 & 0.68 \\
Caeca & 0.59 & 0.57 & 0.50 & 0.56 & 0.52 & 0.02 & 0.62 \\
Abdominal fat & 0.83 & 0.88 & 0.74 & 0.88 & 0.90 & 0.06 & 0.92 \\
Spleen & 0.13 & 0.11 & 0.11 & 0.11 & 0.11 & 0.01 & 0.85 \\
Thymus & 0.28 & 0.38 & 0.34 & 0.33 & 0.26 & 0.02 & 0.48 \\
Bursa offabricius & 0.17 & 0.21 & 0.16 & 0.22 & 0.27 & 0.01 & 0.06 \\
\hline T0: chicks recer
\end{tabular}

T0: chicks received basal feed, T1: feed with 2.5\% PSM, T2: feed with 1\% SPSM, T3: feed with 2.5\% SPSM,

T4: feed with 5\% SPSM, BW: body weight, SEM: standard error of the mean 
Table 5. Complete Blood Indices of Broilers at Day 36

\begin{tabular}{|c|c|c|c|c|c|c|c|}
\hline Variables & T0 & $\mathrm{T} 1$ & $\mathrm{~T} 2$ & $\mathrm{~T} 3$ & $\mathrm{~T} 4$ & SEM & $\mathrm{P}$ value \\
\hline Erythrocytes $\left(10^{12} / \mathrm{L}\right)$ & 3.24 & 3.00 & 3.05 & 3.11 & 2.74 & 1.70 & 0.93 \\
\hline Haemoglobin (g/dL) & 20.1 & 11.3 & 11.3 & 8.67 & 9.92 & 1.68 & 0.21 \\
\hline Haematocrits (\%) & 43.4 & 39.4 & 40.3 & 34.7 & 36.5 & 1.88 & 0.64 \\
\hline $\operatorname{MCV}(\mathrm{fl})$ & 134 & 132 & 135 & 134 & 134 & 0.59 & 0.48 \\
\hline $\mathrm{MCH}(\mathrm{pg})$ & $37.7^{\mathrm{a}}$ & $37.7^{\mathrm{a}}$ & $36.1^{\mathrm{ab}}$ & $36.2^{\mathrm{ab}}$ & $35.5^{\mathrm{b}}$ & 0.26 & 0.02 \\
\hline $\mathrm{MCHC}(\mathrm{g} / \mathrm{dL})$ & $28.2^{\mathrm{ab}}$ & $28.8^{\mathrm{a}}$ & $27.5^{\mathrm{bc}}$ & $27.3^{b c}$ & $26.7^{\mathrm{c}}$ & 0.20 & 0.01 \\
\hline RDW-SD $\left(10^{-15} \mathrm{~L}\right)$ & 51.6 & 50.3 & 51.6 & 54.1 & 53.4 & 0.58 & 0.25 \\
\hline RDW-CV (\%) & 10.1 & 10.1 & 10.3 & 10.7 & 10.5 & 0.11 & 0.41 \\
\hline $\operatorname{MPV}\left(10^{-15} \mathrm{~L}\right)$ & 8.68 & 8.17 & 8.54 & 8.51 & 8.86 & 0.09 & 0.15 \\
\hline PDW (\%) & 8.25 & 6.15 & 7.21 & 7.86 & 7.24 & 0.27 & 0.13 \\
\hline Leukocytes $\left(10^{9} / \mathrm{L}\right)$ & 126 & 112 & 138 & 99.4 & 106 & 6.86 & 0.39 \\
\hline Heterophils $\left(10^{9} / \mathrm{L}\right)$ & 22.1 & 10.3 & 19.7 & 11.4 & 10.5 & 1.80 & 0.09 \\
\hline Lymphocytes $\left(10^{9} / \mathrm{L}\right)$ & 112 & 102 & 119 & 88.0 & 95.6 & 6.47 & 0.58 \\
\hline Thrombocytes $\left(10^{9} / \mathrm{L}\right)$ & 12.9 & 11.5 & 12.7 & 12.7 & 13.1 & 0.44 & 0.82 \\
\hline \multicolumn{8}{|c|}{${ }^{\mathrm{a}, \mathrm{b}}$ Within the same row, the means with different superscript characters varied substantially $(\mathrm{P}<0.05)$} \\
\hline $\begin{array}{l}\text { T0: chicks received basal } \\
\text { T4: feed with } 5 \% \text { SPSM, } \\
\text { corpuscular haemoglobin } \\
\text { CV: red blood cell distrib } \\
\text { distribution width, SEM: }\end{array}$ & $\begin{array}{l}\text { 1: feed } \\
\text { mean co } \\
\text { tration, } \\
\text { idth-co } \\
\text { d error }\end{array}$ & $\begin{array}{l}2.5 \% \mathrm{P} \\
\text { scular v } \\
\text { W-SD: } 1 \\
\text { ient var }\end{array}$ & $\begin{array}{l}\text { I, T2: fee } \\
\text { me, MCF } \\
\text { blood ce } \\
\text { on, MPV }\end{array}$ & $\begin{array}{l}\text { ith } 1 \% \\
\text { lean cor } \\
\text { stributic } \\
\text { ean plat }\end{array}$ & $\begin{array}{l}\text { M, T3: } \\
\text { ular hat } \\
\text { idth-sta } \\
\text { volume, }\end{array}$ & $\begin{array}{l}\text { with } 2.5 \% \\
\text { globin, } \mathrm{M} \\
\text { rd deviatio } \\
\mathrm{W} \text { : platele }\end{array}$ & $\begin{array}{l}\text { SPSM, } \\
\text { HC: mean } \\
\text {, RDW- }\end{array}$ \\
\hline
\end{tabular}

Table 6. Serum Biochemical Indices of Broilers at Day 36

\begin{tabular}{|c|c|c|c|c|c|c|c|}
\hline Variables & T0 & $\mathrm{T} 1$ & $\mathrm{~T} 2$ & $\mathrm{~T} 3$ & $\mathrm{~T} 4$ & SEM & $\mathrm{P}$ value \\
\hline $\begin{array}{l}\text { Total cholesterol } \\
(\mathrm{mg} / \mathrm{dL})\end{array}$ & 150 & 116 & 124 & 131 & 140 & 4.16 & 0.07 \\
\hline $\begin{array}{l}\text { Total triglyceride } \\
(\mathrm{mg} / \mathrm{dL})\end{array}$ & 81.2 & 47.2 & 51.4 & 66.1 & 65.1 & 4.30 & 0.09 \\
\hline $\mathrm{LDL}(\mathrm{mg} / \mathrm{dL})$ & 146 & 112 & 119 & 124 & 132 & 4.13 & 0.09 \\
\hline HDL (mg/dL) & $65.0^{\mathrm{bc}}$ & $62.6^{\mathrm{c}}$ & $78.3^{\mathrm{ab}}$ & $79.8^{\mathrm{a}}$ & $67.8^{\mathrm{abc}}$ & 2.25 & 0.04 \\
\hline Cholesterol/HDL ratio & $2.80^{\mathrm{a}}$ & $1.92^{\mathrm{b}}$ & $1.60^{\mathrm{b}}$ & $1.65^{\mathrm{b}}$ & $2.22^{\mathrm{ab}}$ & 0.13 & 0.02 \\
\hline Glucose (mg/dL) & 297 & 230 & 206 & 285 & 254 & 13.4 & 0.18 \\
\hline Total protein $(\mathrm{g} / \mathrm{dL})$ & $3.59^{\mathrm{a}}$ & $2.70^{\mathrm{bc}}$ & $2.89^{\mathrm{bc}}$ & $2.52^{\mathrm{c}}$ & $3.15^{\mathrm{ab}}$ & 0.10 & $<0.01$ \\
\hline Albumin (g/dL) & $1.53^{\mathrm{a}}$ & $1.19^{\mathrm{bc}}$ & $1.26^{\mathrm{bc}}$ & $1.18^{\mathrm{c}}$ & $1.41^{\mathrm{ab}}$ & 0.04 & $<0.01$ \\
\hline Globulin (g/dL) & $2.06^{\mathrm{a}}$ & $1.51^{\mathrm{bc}}$ & $1.63^{\mathrm{bc}}$ & $1.34^{\mathrm{c}}$ & $1.74^{\mathrm{ab}}$ & 0.06 & $<0.01$ \\
\hline Uric acid (mg/dL) & 5.60 & 3.19 & 4.50 & 4.33 & 4.23 & 0.32 & 0.23 \\
\hline Creatinine $(\mathrm{mg} / \mathrm{dL})$ & $0.07^{\mathrm{a}}$ & $0.05^{\mathrm{b}}$ & $0.05^{\mathrm{b}}$ & $0.03^{\mathrm{b}}$ & $0.05^{\mathrm{b}}$ & $<0.01$ & $<0.01$ \\
\hline $\operatorname{AST}(\mathrm{U} / \mathrm{L})$ & 294 & 322 & 253 & 238 & 268 & 12.5 & 0.22 \\
\hline $\operatorname{ALT}(\mathrm{U} / \mathrm{L})$ & $2.35^{\mathrm{a}}$ & $1.59^{\mathrm{ab}}$ & $1.01^{\mathrm{b}}$ & $1.10^{\mathrm{b}}$ & $1.46^{\mathrm{ab}}$ & 0.14 & 0.02 \\
\hline
\end{tabular}

concentrations of total protein, albumin and globulin of broilers (Table 6). To date, the definite reason for such conditions is not known. Typically, blood protein concentration may reflect the degree of protein synthesis in the liver. Apata (2011) documented that the reduction in serum total protein indicated a de- crease in protein synthesis, which might be due to a low protein intake or low digestibility. Higher fibre content has usually been attributed to the reduction in protein digestibility in broilers (Apata, 2011). Taking a consideration that diets containing PSM or SPSM contained greater fibre content that that of control 
Table 7. Selected Intestinal Bacterial Populations of Broilers at Day 36

\begin{tabular}{lccccccc}
\hline Variables (log cfu/g) & T0 & T1 & T2 & T3 & T4 & SEM & P value \\
\hline Ileum & 7.73 & 6.46 & 6.30 & 5.63 & 5.91 & 0.26 & 0.08 \\
$\quad$ Coliform & 5.54 & 6.87 & 5.63 & 5.62 & 5.26 & 0.21 & 0.12 \\
LNE & 7.74 & 7.35 & 6.30 & 5.99 & 5.91 & 0.28 & 0.12 \\
$\quad$ Enterobacteriaceae & 8.01 & 9.67 & 8.87 & 9.15 & 9.94 & 0.30 & 0.28 \\
LAB & $1.04^{\mathrm{b}}$ & $1.52^{\mathrm{a}}$ & $1.48^{\mathrm{a}}$ & $1.67^{\mathrm{a}}$ & $1.74^{\mathrm{a}}$ & 0.08 & 0.02 \\
LAB/coliform ratio & & & & & & & \\
Cecum & 8.58 & 7.65 & 8.86 & 8.12 & 8.05 & 0.22 & 0.45 \\
Coliform & 6.85 & 6.15 & 7.35 & 6.46 & 6.41 & 0.27 & 0.68 \\
LNE & 8.65 & 7.74 & 8.98 & 8.17 & 8.08 & 0.22 & 0.43 \\
$\quad$ Enterobacteriaceae & 11.7 & 11.4 & 11.6 & 11.6 & 11.4 & 0.07 & 0.42 \\
LAB & 1.37 & 1.53 & 1.32 & 1.49 & 1.46 & 0.05 & 0.64 \\
LAB/coliform ratio & & & & & & \\
\hline
\end{tabular}

${ }^{\mathrm{a}, \mathrm{b}}$ Within the same row, the means with different superscript characters varied substantially $(\mathrm{P}<0.05)$

T0: chicks received basal feed, T1: feed with 2.5\% PSM, T2: feed with 1\% SPSM, T3: feed with 2.5\% SPSM, T4: feed with 5\% SPSM, LNE:lactose negative Enterobacteriaceae, LAB: lactic acid bacteria, cfu: colony forming unit

Table 8. Fatty Acid Composition and Colour of Broiler Meats at Day 36

\begin{tabular}{lrrrrrrr}
\hline Variables & T0 & T1 & T2 & T3 & T4 & SEM & p value \\
\hline Fatty acids & & & & & & & \\
Total SFA (g/100 g) & 0.22 & 0.16 & 0.34 & 0.31 & 0.24 & 0.02 & 0.08 \\
Total UFA (g/100 g) & 0.41 & 0.30 & 0.63 & 0.60 & 0.48 & 0.04 & 0.09 \\
n-3 PUFA (mg/100 g) & 8.83 & 4.46 & 8.98 & 6.46 & 7.77 & 0.67 & 0.17 \\
n-6 PUFA (mg/100 g) & 136 & 96.8 & 192 & 177 & 141 & 12.4 & 0.11 \\
Meat colour & & & & & & & \\
L* (lightness) & $49.1^{\text {bc }}$ & $50.6^{\text {abc }}$ & $51.8^{\mathrm{a}}$ & $51.0^{\mathrm{ab}}$ & $48.9^{\mathrm{c}}$ & 0.30 & 0.01 \\
a* (redness) $^{\text {* }}$ & 4.41 & 4.99 & 4.11 & 3.97 & 4.61 & 0.17 & 0.35 \\
b $^{*}$ (yellowness) & $8.99^{\mathrm{c}}$ & $10.2^{\mathrm{b}}$ & $9.60^{\mathrm{bc}}$ & $11.3^{\mathrm{a}}$ & $8.95^{\mathrm{c}}$ & 0.18 & $<0.01$
\end{tabular}

${ }^{\mathrm{a}, \mathrm{b}}$ Within the same row, the means with different superscript characters varied substantially $(\mathrm{P}<0.05)$

T0: chicks received basal feed, T1: feed with 2.5\% PSM, T2: feed with 1\% SPSM, T3: feed with 2.5\% SPSM,

T4: feed with 5\% SPSM, SFA: saturated fatty acids, UFA: unsaturated fatty acids, PUFA: polyunsaturated fatty acids, SEM: standard error of the mean

diet, the reduced concentrations of total protein, albumin and globulin in the PSM or SPSM fed birds may be due to the reduced protein digestibility in these respective birds. Creatinine has traditionally been used as a marker for protein metabolism. Increased muscle protein catabolism and consequently greater amounts of creatinine in broiler circulation are generally associated with increased corticosterone levels during stressful situations (Sugiharto, 2020b). In this investigation, feeding PSM or SPSM to broilers resulted in reduced $(\mathrm{P}<0.05)$ levels of creatinine in their serum when compared to control. As a result, our findings showed that PSM and SPSM might help broilers cope with stressful conditions. Similar to creatinine, the ALT levels often rise in broilers during stressful circumstances, indicating oxidative stress and injury to internal organs such as the liver and kidney (Sugiharto, 2020b). The blood levels of ALT was lower $(\mathrm{P}<0.05)$ in broilers fed SPSM at 1 and $2.5 \%$ of feed in this study (Table 6 ). Owing to this, the antioxidative properties of SPSM seemed to alleviate the oxidative stress in broilers during rearing, resulting in lower serum ALT level.

In our current investigation, the LAB to coliform ratio in the ileum of broilers given PSM or SPSM was greater $(\mathrm{P}<0.05)$ than in those fed a control diet (Table 7). In accordance with this, coliform counts in the ileum of broilers given PSM or SPSM tended $(\mathrm{P}=0.08)$ to be lower than those fed a control diet. The reduced coliform levels in the ileum of broilers were due to the antibacterial action of some antibacterial agents such as alkaloids, steroids, flavonoids, saponins, papain, and terpenoids in PSM or SPSM (Sugiharto, 2020a). However, the dietary treatment had no meaningful effect on the bacterial population in the caecum of broilers.

Table 8 describes fatty acid composition and colour of broiler meats collected at day 36 . When comparing meat from broilers given a PSM-diet to meat from other broilers, total SFA was found to be re- 
duced $(\mathrm{P}=0.08)$. This pattern actually corresponded to the amount of triglycerides in serum of broiler as described above. Higher insoluble fibre consumption appeared to decrease triglyceride synthesis in the liver (Sarikhan et al., 2009), leading to lower SFA deposition in meats. In terms of total UFA content, meats taken from broilers fed 1 or $2.5 \%$ SPSM tended $(\mathrm{P}=0.09)$ to have a greater total UFA content. Herchi et al. (2015) reported that germination lowered total fat and SFA contents, while increased PUFA content of flaxseed. Owing to this fact, feeding SPSM may therefore result in increased PUFA deposition in broiler meats. Yet, because the fatty acid composition of SPSM and broiler diets was not determined, the latter assumption should be treated with caution. The colour of broiler meat is one of the most important physical characteristics since it influences consumer choice. The pale-soft-exudative (PSE) and dark-firm-dry (DFD) condition of meats has traditionally been determined on the basis of the lightness $\left(\mathrm{L}^{*}\right)$ values. There was no definite trend in the $\mathrm{L}^{*}$ values of broiler breast meats in this study. Nonetheless, all meats from each treatment group appeared to be within the normal range, as Kralik et al. (2014) noticed that normal broiler meats had $L^{*}$ values ranging from 44 to 53 . There was likewise no specific trend in the $b^{*}$ values of broiler meats. Kralik et al. (2014) categorized the $\mathrm{b}^{*}$ values for PSE as 12.76, normal 9.63, and DFD 7.89 , indicating that the results appeared to be within the normal range.

\section{CONCLUSION}

Dietary incorporation of SPSM improved immune competence, blood lipid profile and gut bacterial population of broilers. Feeding SPSM up to 5\% had no detrimental effect on daily weight gain and feed consumption, but it impaired feed efficiency when included at $5 \%$ of feed.

\section{ACKNOWLEDGEMENT}

The Directorate of Research and Community Service, Directorate General of Higher Education, Ministry of Education, Culture, Research and Technology, Republic of Indonesia supported this study (Contract Nr. 187-17/UN7.6.1/PP/2021).

\section{CONFLICT OF INTEREST}

The authors had no competing interest.

\section{REFERENCES}

Adegbeye, M. J., Oloruntola, O. D., Asaniyan, E. K., Agunbiade, B., Oisagah, E. A. and Ayodele, S. O. 2020. Pawpaw, black cumin, and mustard seed meals dietary supplementation in broiler chickens: effect on performance, gut microflora, and gut morphology. J. Agr. Sci. Tech. 22 (5):1235-1246.

Adesuyi, A. O. and K. O. Ipinmoroti. 2011. The nutritional and functional properties of the seed flour of three varieties of Carica papaya. Curr. Res. Chem. 3:70-75.

Aengwanich, W. 2007. Effects of high environmental temperature on blood indices of Thai indigenous chickens, Thai indigenous chickens crossbred and broilers. Int. J. Poult. Sci. 6:427-430.

Apata, D. F. 2011. Effect of Terminalia catappa fruit meal fermented by Aspergillus niger as replacement of maize on growth performance, nutrient digestibility, and serum biochemical profile of broiler chickens. Biotechnol. Res. Int. https:// doi.org/10.4061/2011/907546

Azevedo, L. A. and P. C. B.Campagnol. 2014. Papaya seed flour (Carica papaya) affects the technological and sensory quality of hamburgers. Int. Food Res. J. 21(6):2141-2145.

Bolton W. Poultry Nutrition. MAFF Bulletin No.174. HMSO, London. 1967.

Bolu, S. A. O., F. E. Sola-Ojo, O. A. Olorunsanya and K. Idris. 2009. Effect of graded levels of dried pawpaw (Carica papaya) seed on the performance, haematology, serum biochemistry and carcass evaluation of chicken broilers. Int. J. Poult. Sci. 8(9):905-909.

Harmon, B. G. 1998. Avian heterophils in inflammation and disease resistance. Poult Sci. 77(7):972977.

Herchi, W., S. Bahashwan, K. Sebei, H. Ben Saleh, H. Kallel and S. Boukhchina. 2015. Effects of germination on chemical composition and antioxidant activity of flaxseed (Linumusitatissimum L) oil. GrasasAceites. 66 (1): $\mathrm{e} 057$.

Hooda, S. and S. Jood. 2003. Effect of soaking and germination on nutrient and antinutrient contents of fenugreek (Trigonellafoenumgraecum L.). J. Food Biochem. 27:165-176.

Kontecka, H., J. M. Książkiewicz and L. Nogowski. 1999. Effects of different stressors on laying rate and selected blood indices in reproductive ducks. J. Anim. Feed Sci. 8(1):63-72.

Kralik, G., I. Djurkin, Z. Kralik, Z. Skrtic and Z. Radisic. 2014. Quality indicators of broiler breast meat in relation to colour. Anim. Sci. Papers Rep. 32(2):173-178.

Maxwell, M. and G. Robertson. 1998. The avian heterophil leucocyte: A review. World's Poult. Sci. J. 54(2):155-178.

Nkhata, S. G., E. Ayua, E. H. Kamau and J. B. Shingiro. 2018. Fermentation and germination improve nutritional value of cereals and legumes through activation of endogenous enzymes. Food Sci. Nutr. 6(8):2446-2458.

Ouyang, K., M. Xu, Y. Jiang and W. Wang. 2016. Effects of alfalfa flavonoids on broiler perfor- 
mance, meat quality, and gene expression. Can. J. Anim. Sci. 96(3):332-341

Razdan, A., D. Pettersson and J. Pettersson. 1997. Broiler chicken body weights, feed intakes, plasma lipid and small-intestinal bile acid concentrations in response to feeding of chitosan and pectin. Br. J. Nutr. 78(2):283-291.

Sarikhan, M., H. A. Shahryar, K. Nazer-Adl, B. Gholizadeh and B. Behesht. 2009. Fecal excretion of cholesterol and bile acids. Int. J. Agric. Biol. 11(1):73-76.

Sehrawat, N., M.Yadav, S.Kumar, S. K.Upadhyay, M.Singh and A. K.Sharma. 2020. Review on health promoting biological activities of mungbean: A potent functional food of medicinal importance. Plant Arch. 20:2969-2975.

Sugiharto, S. 2020a. Papaya (Carica papaya L.) seed as a potent functional feedstuff for poultry - A review. Vet. World. 13(8):1613-1619.

Sugiharto, S. 2020b. Alleviation of heat stress in broiler chicken using turmeric (Curcuma longa) - a short review. J. Anim. Behav. Biometeorol. $8(3): 215-222$.

Sugiharto, S. 2021. The use of sprouted grains as dietary feed ingredients for broilers - a brief overview. Livest. Res. Rural Dev. 33(3). http:// www.lrrd.org/lrrd33/3/sgh_u3338.html

Sugiharto, S., T. Yudiarti, I. Isroli and E. Widiastuti. 2018. The Potential of tropical agro-industrial by-products as a functional feed for poultry. Iran. J. Appl. Anim. Sci. 8(3):375-385.

Sugiharto, S., T. Yudiarti, I. Isroli, E. Widiastuti and E. Kusumanti. 2017. Dietary supplementation of probiotics in poultry exposed to heat stress a review. Ann. Anim. Sci. 17(3):591-604.

Tarek, K., M. Mohamed, B. Hassina and I. Messaouda. 2013. Histological study of the bursa of fabricius of broiler chickens during heat stress. Int. J. Poult. Sci. 12:377-378. 